\title{
AIDS related changes in pattern of sexually transmitted disease (STD) in an STD clinic in Copenhagen
}

\author{
CARSTEN SAND PETERSEN, JØRGEN SØNDERGAARD, \\ GUNHILD LANGE WANTZIN
}

From the Department of Dermatovenereology, Bispebjerg Hospital, Copenhagen, Denmark

SUMMARY Testing for antibodies against human immunodeficiency virus (HIV) was introduced in 1984 in this major sexually transmitted disease (STD) clinic in Copenhagen, which is attended by about 10000 new patients each year. From 1984 to 1987 the proportion of patients examined for antibodies to HIV rose from $6 \%$ to $32 \%$. The overall incidence of HIV antibody positivity decreased from $30 \%$ in 1984 to $3 \%$ in 1987 , the combined result of decreased positivity in high risk patients tested and increased screening in low risk patients. HIV antibody positivity has been confined largely to homosexual men and drug addicts. Since 1985, however, 21 out of $2623(0 \cdot 8 \%)$ heterosexuals who were not drug addicts were found to be HIV antibody positive.

During 1984-6 the incidence of STDs most often encountered in high risk groups (syphilis and gonorrhoea) decreased by $64 \%$ and $41 \%$ respectively, whereas the incidence of diseases most often diagnosed in low risk groups (condylomata acuminata and genital herpes) increased by $70 \%$ and $34 \%$ respectively in the same period. The addition of HIV infection to the list of STDs requires the allocation of more resources to the STD clinics to enable these clinics to handle this new problem. Screening for all patients attending an STD clinic for antibodies to HIV must be considered, and in our area it would be cost effective.

The addition of the potentially lethal human immunodeficiency virus (HIV) infection to the large number of sexually transmitted diseases (STDs) has had a pronounced influence on the resources used to diagnose and treat these infections in STD clinics. Public health programmes have been developed and launched to minimise the risk of further spread of HIV infection outside the known risk groups. These programmes should generally result in the decreased incidence of all common STDs.

Our experience from 1984 to 1987 with HIV antibody testing of patients attending an STD clinic and the impact of AIDS on the incidence of other STDs is described in this study.

\section{Patients and methods}

In 1984 screening for antibodies to HIV began on a

Address for reprints: Dr Carsten Sand Petersen, Department of Dermatovenereology, Bispebjerg Hospital, 2400 NV Copenhagen, Denmark

Accepted for publication 23 December 1987 large scale for homosexual men and drug addicts attending this STD clinic located in the centre of Copenhagen. An enzyme linked immunosorbent assay (ELISA) was used, and HIV antibody positivity was confirmed by western blotting. ' Since 1985 all patients attending the clinic have had the opportunity of being tested for antibody to HIV. Not all patients are yet tested routinely, but known high risk patients are always offered testing, whereas heterosexuals who are not drug addicts are only tested for antibodies to HIV on request.

\section{Results}

An increasing number of patients attending the clinic have been tested for antibodies to HIV. The numbers of patients tested in relation to numbers of new patients were: $457 / 8137(6 \%)$ in $1984,1877 / 9105$ $(21 \%)$ in $1985,1961 / 9422(21 \%)$ in 1986 , and $1405 /$ $4417(32 \%)$ in the first six months of 1987. At the same time a gradual and pronounced decrease in the proportion of HIV antibody positive patients has occurred, from $30 \%$ in 1984 to $3 \%$ in 1987 (table 1). 
Table 1 Incidence of patients with antibody to human immunodeficiency virus (HIV) in different categories attending an STD clinic in Copenhagen, 1984-7

\begin{tabular}{|c|c|c|c|c|}
\hline \multirow[b]{2}{*}{ Patients } & \multicolumn{4}{|c|}{ No (\%) positive/No tested for antibody to HIV in: } \\
\hline & 1984 & 1985 & 1986 & 1987 (first six months) \\
\hline $\begin{array}{l}\text { Homosexual men } \\
\text { Drug addicts } \\
\text { Prostitutes (all drug addicts) } \\
\text { Heterosexual men (not drug addicts) } \\
\text { Heterosexual women (not drug addicts) }\end{array}$ & 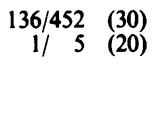 & 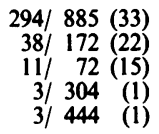 & $\begin{aligned} & 145 / 489(30) \\
& 50 / 433(12) \\
& 8 / 81(10) \\
& 8 / 456(2) \\
& 4 / 502 \text { (1) }\end{aligned}$ & $\begin{array}{rrr}26 / 300 & 30 \\
10 / & 153 & (7) \\
1 / & 35 & (3) \\
3 / & 450 & (1) \\
0 / & 467\end{array}$ \\
\hline Total & $137 / 457 \quad(30)$ & $349 / 1877(19)$ & $215 / 1961(11)$ & $40 / 1405 \quad(3)$ \\
\hline
\end{tabular}

This was the combined result of increased HIV antibody screening of low risk groups and decreased HIV antibody positivity in high risk groups, including homosexual men and drug addicts (table 1). HIV infection has so far been confined to the well known risk groups. Since 1985 , however, $21(0 \cdot 8 \%)$ of 2623 heterosexuals who were not drug addicts were found to be HIV antibody positive (table 1). Thirteen of those 21 patients had had sexual intercourse with people belonging to the high risk groups.

From 1984 to 1986 the number of diagnosed cases of syphilis and gonorrhoea decreased appreciably (table 2 ). The prevalence of syphilis reduced by $64 \%$ and gonorrhoea by $41 \%$. In the same period we saw only a minor decrease $(10 \%)$ in the diagnosed cases of chlamydial infections and increases in the incidences of condylomata acuminata $(70 \%)$ and genital herpes $(34 \%)$. The incidence of syphilis decreased in homosexual men from $55 / 92(60 \%)$ in 1984 , to $65 / 112$ $(58 \%)$ in 1985 , and $10 / 33(30 \%)$ in 1986.

\section{Discussion}

From 1984 to 1987 HIV antibody testing was performed to a greater extent in low risk groups. Extensive HIV antibody testing requires a considerable proportion of the resources available to the clinic, which before testing includes giving personal information about the test, and the consequences of a negative and a positive test result, and after testing includes consultation to give each patient the result of the test. Giving safer sex information, both written and oral, to

Table 2 Incidence of sexually transmitted diseases (STDs) in an STD clinic in Copenhagen, 1984-6

\begin{tabular}{lrrr}
\hline & \multicolumn{3}{c}{ No of cases in: } \\
\cline { 2 - 4 } Disease & 1984 & 1985 & 1986 \\
\hline Syphilis & 92 & 112 & 33 \\
Gonorrhoea & 1916 & 1538 & 1128 \\
Chlamydial infection & 1775 & 1716 & 1605 \\
Genital warts & 448 & 650 & 763 \\
Herpes & 218 & 281 & 293 \\
\hline
\end{tabular}

patients tested for antibody to HIV is also time consuming. HIV antibody positive patients are further offered regular health examinations to detect early signs and symptoms of AIDS and AIDS related complex.

The resources released by the decreased incidence of syphilis and gonorrhoea are more than counteracted by the resources needed for diagnosing and treating the increased incidence of condylomata acuminata and genital herpes. Condylomata acuminata are often resistant to treatment and require multiple visits for cure. ${ }^{2}$ The increased number of patients with genital warts was also followed by an increased incidence of premalignant and malignant sequelae to human papilomavirus infection, such as cervical dysplasia, carcinoma in situ of the cervix, and Bowenoid papulosis. This change in disease pattern makes it essential to allocate further resources to the STD clinic.

The decreased HIV antibody positivity observed in high risk groups may be the result of decreased promiscuity caused by the fear of contracting AIDS and by the increased use of condoms for casual sexual intercourse. It is also, however, due to the increase in testing people with no or low risk behaviour. The message in the public information campaign against AIDS, which recommends decreased promiscuity and the use of condoms for casual sexual intercourse, has reached the high risk groups, as shown by the dramatic decrease in the prevalence of syphilis and gonorrhoea, which are seen more often in the promiscuous members of the high risk groups. ${ }^{3}$ It is, however, somewhat disappointing at the same time to see that the incidence of other STDs is rising, which may indicate that people in low risk groups have not reduced their promiscuity or increased their use of condoms.

About 3000 of the clinic's expected 9000 new visitors will probably be screened for antibodies to HIV in 1987. Of the 6000 patients not tested, 600 will probably belong to high risk groups and 5400 to low risk groups. Based on the 1987 incidence of antibody to HIV in the different groups, general screening of all patients attending the clinic would therefore disclose a further 16 HIV infected heterosexuals who are not drug 
addicts and 48 HIV infected homosexuals or drug addicts.

It is generally considered to be sound to know the HIV antibody status of patients, especially if they belong to the low risk group. By knowing the HIV antibody status we can reduce the risk of spread of HIV to the heterosexual population. ${ }^{4}$ The overall estimated incidence since 1981 of HIV antibody in $0.8 \%$ of heterosexuals who are not drug addicts may be too low, because the test is often requested by heterosexuals with only a minimal risk of positive results. The cost of screening all 9000 patients attending the clinic would be about $1 \cdot 1$ million Danish kroner. The finding of an additional 16 heterosexuals who are HIV antibody positive by a general screening procedure would probably prevent at least two cases of AIDS, which would make the screening cost effective.

\section{References}

1 Safai B, Sargadharon MG, Groopman JE. Seroepidemiological studies of human T-lymphotropic retrovirus type III in acquired immunodeficiency syndrome. Lancet 1984;i:1438-40.

2 Petersen CS, Worm AM, Kroon S, Tikjøb G. Podophyllotoxin 5\% and podophyllin $20 \%$ in the treatment of ano-genital warts. A comparative double-blind study. European Journal of Sexually Transmitted Diseases 1985;2:155-8.

3 Petersen CS, Pedersen NS. The profile of early infectious syphilis in Denmark. Dan Med Bull 1983;30:49-51.

4 Goedart JJ. What is safe sex? Suggested standards linked to testing for human immunodeficiency virus. $N$ Engl $J$ Med 1987;316:139-42. 